TURIZAM

Volume 19, Issue 1

1-12 (2015)

\title{
The Relationship of a Foreign Tour Operator in Serbia towards Tourists Based on the Example of TUI
}

\author{
Marija Šuleić, Aleksandra Dragin, Vanja Dragićević* \\ Received: June 2014 | Accepted: September 2014
}

\begin{abstract}
Tourism represents a widespread phenomenon in which around a billion of people participates, so that it is understandable that a small percentage of the dissatisfied represents a serious contingent. Therefore the complaints of the users of travel agencies' services arise. In order to protect itself, each responsible company must undertake a package of various measures, aiming at increasing the quality of providing services, in other words, increasing its competitiveness. EU tourists are protected in large measure by the regulations associated with consumers' protection because different travel guidelines have been introduced. Serbia is also on the way of the adoption of all measures. The aim of this research was to analyze which mechanisms are used by TUI in order that tourists be satisfied with their purchased arrangements and which approach TUI applies in Serbia for solving possible complaints of end-users of its services. The research results can be useful not only for travel agencies, but for tourists as well.
\end{abstract}

Key words: complaints of tourists, TUI, ethical codex, the Frankfurt list, Serbia.

\section{Introduction}

The process of introducing the Travel Guidelines was started in EU even in 1993 (http://archiv. jura.uni-saarland.de/projekte/Bibliothek/text.php?id=349) where the high standards of the protection of tourists-consumers were established sothat tour operators were considered responsible for an incomplete holiday, physical injuries on the travel or during the realization of the holiday and the damage of a client's property (Čavlek, 1998).

In Serbia, the tourism market and business activities of travel agencies are regulated by a set of laws (e.g by Law on Tourism, Law on Consumer Protection, Law on the Protection of the Competition) and by the standards of the associations of travel agencies, established for their members, in other words, by general terms and conditions of business and, also, with other following regulations such as the Codex of Business Ethics (www.kg-cci.co.rs/pdf/zakoni/ kodeks_poslovne_etike), (Dragin, 2011; Simat, Dragin, Dragićević, 2012; Simat, Dragin, 2012). The sector of the tourism inspection of a competent ministry of the Republic of Ser-

* University of Novi Sad, Faculty of Sciences, Department of Geography, Tourism and Hotel Management, Trg Dositeja Obradovića 3, 21000 Novi Sad, Serbia, Corresponding author: marijasuleic@yahoo.com 
bia, according to the Annual and Quarterly Operational Work Plans, conducts an inspection visit of lawful business operations of tourist economy and the use of prescribed quality standards in the field of tourism every year.Besides planned regular controls, even permanent controls are being conducted with priority on the basis of the report of citizens, dissatisfied service users in tourism and catering (http://www.turizam.merr.gov.rs/images/stories/turisticka\%2o inspekcija/izvestaji/Izvestaj\%200\%2oradu\%2oSektora\%2oturisticke\%2oinspekcije\%20u\%20 2010.\%2ogodini.pdf). In the five-year period from 2008 to 2012, the Ministry, due to determined irregularities in the business operations of travel agencies besides undertaken ruling and penal measures, took away 28 licences from travel agencies as tour operators. In 2009 the Ministry announced most descisions for taking away the licences (nine agencies) while only two agencies were punished in this way in 2012 (http://www.turizam.merr.gov.rs/images/stories/materijal/Oduzete\%2olicence\%2oturistickim\%2oagencijama.pdf). One can notice that the decisions for revoking the licence were being brought to a large extent on the basis of two or more reasons, in other words, irregularities. Failure to fulfill general travel conditions represents the most frequent irregularity, more precisely, unfulfilled travel plans, a cancelled travel by tour operators in less than 5 days and an unrealized refund of money for unrealized services within the statuory time of 15 days. As it was examined in the last five-year term (2008-2012), travel agencies used mostly this form of unethical business operations in 2010 (http://www. turizam.merr.gov.rs/images/stories/materijal/Oduzete\%2olicence\%2oturistickim\%2oagencijama.pdf). Moreover, uncommonly frequent irregularities in the work of agencies are: unprovided accommodation scheduled by the travel programme, unconcluded contract with third parties (transport company, accommodation service provider, foreign partner), the lack of an employee with an associate degree in tourism, economy or in social sciences and with, at least, one year of work experience and the failure to fulfill the conditions on which basis the licence for the organization of travel has been issued, because the proper travel warranty has not been ensured in case of insolvence and the travel warranty for the compensation of damages to a passenger, made by not fulfilling, partially fulfilling or untidily fulfilling contractual obligations.

According to the information of the Tourism Inspection of the Ministry of Economy and Regional Development of the Republic of Serbia, there are the ten most frequent objections of tourists on the failure to fulfill the travel contract:

- Degree of comfort (in rooms, there are not a safe, minibar, air-conditioner, TV, extra bed instead of a standard size bed...);

- Location of the accommodation facility (greater distance of the hotel from the beach and the centre than the one stated in the travel programme;

- Category of the accommodation facility (passengers transferred to another hotel due to a double booking; complaints of passengers on the hotel's failure to fulfill the conditions for the category it possesses; passengers accommodated in the facility which is not categorized, but it has been stated in the travel programme that the facility possesses a certain category;

- Passengers believe that the charter flights arrangement lasted one day shorter, when the departure time is in the late evening and the return time is in the early morning;

- Cancelled travel by the agency because a sufficient number of passengers has not been registered;

- Duty of paying extra money for the extended use of rooms on the last day of stay;

- Noise in close vicinity of the accommodation facility (music from a coffee bar, building site); 
- Different price of optional excursions depending on it who organizes them (much lower via local agencies than the price charged by our tour operators;

- Breakdown of the bus and dysfunction of the air-conditioner in the bus;

- Extra money for the services which had to be included in the arrangement price (ferry, tickets...) (www.blic.rs/Vesti/Tema-Dana/198198/Deset-najcescih-prevara-turistickih-agencija)

Taken from the Tourism Inspection of the Ministry of Economy and Regional Development of the Republic of Serbia.

If a tour operator is a member of YUTA as most travel agencies in Serbia are its members nowadays, passengers are advised to try and solve all their complaints via the Arbitral Tribunal of YUTA. For potential compensation for damages, passengers are required to state the objection on the spot, to contact the agencies on return and, in the last resort of a dissatisfactory solution by the agency, to seek help from the tourism inspection (www.yuta.rs). Although the arbitration is voluntary and cannot be imposed by the tourist organization, the Association of Consumers views this way of the problem solution as inadequate and considers that YUTA and its members abuse their position on the market in this way. However, agencies deny it and consider that the arbitration is one of faster ways of the dispute solution for the reason that the lawsuit at State Court is not simple and requires money, lawyers, witnesses and various kinds of evidence of the damage sufferance (http://potrosac.info/novosti/).

Table 1. Objections and complaints of tourists submitted to the YUTA arbitration:

\begin{tabular}{|c|c|c|c|c|c|c|c|c|}
\hline Year & $\begin{array}{l}\text { Number of } \\
\text { objections }\end{array}$ & $\begin{array}{l}\text { Number of } \\
\text { comlaints }\end{array}$ & $\begin{array}{l}\text { Fully } \\
\text { received } \\
\text { complaint }\end{array}$ & $\begin{array}{l}\text { Partially } \\
\text { received } \\
\text { complaint }\end{array}$ & $\begin{array}{l}\text { Rejected } \\
\text { complaint }\end{array}$ & Settlement & Withdrawn & $\begin{array}{l}\text { Lack of } \\
\text { authority }\end{array}$ \\
\hline 2005 & 54 & 14 & 8 & 3 & 2 & - & - & - \\
\hline 2006 & 94 & 18 & 1 & 10 & 7 & & & - \\
\hline 2007 & 94 & 29 & - & 15 & 4 & 8 & 2 & \\
\hline 2008 & 124 & 68 & - & 61 & - & 5 & 1 & 1 \\
\hline 2009 & 107 & 57 & 5 & 32 & 18 & 10 & 1 & - \\
\hline 2010 & 71 & 57 & 3 & 26 & 21 & 4 & 2 & 1 \\
\hline 2011 & 89 & 35 & 2 & 18 & 9 & 3 & 2 & 1 \\
\hline 2012 & 84 & 34 & - & 22 & 7 & 3 & 1 & 1 \\
\hline 2013 & 54 & 13 & - & 6 & 2 & 1 & 2 & 2 \\
\hline
\end{tabular}

Source:http://www.yuta.rs/sr/yuta/arbitraza.asp

In Table 1, one can see the number of objections and complaints filed with the YUTA arbitration and the way in which they were being solved. However, it must be poined out that most complaints are usually resolved between agencies and passengers without filing complaints (TUI documentation, 2014).

The research paper analyzes the mechanisms which TUI uses in Serbia in order that tourists be satisfied with the purchased arrangements. Besides this, the subject matter of the research is also complaints, or the approach to resolving the possible complaints of end-users of TUI's services. All arrangements, purchased and realised in the period from July 2012 to July 2014 in TUI in Serbia, are, for these reasons, covered for the needs of this paper. 


\section{The relationship of TUI towards its end-users-tourists}

TUI was founded in 1968. To this day, it has expanded its sales network in 18 countries with over 3,500 offices. There are 120 airplanes, 10 cruisers and 285 hotels in TUI's ownership (TUI documentation, 2014). TUI turnover in financial year 2012-2013 was 18,500,000,0oo euros and the earnings in the same year were $762,000,000$ euros. Final annual salary was $187,000,000$ euros after the deduction of amortization, interest and tax-fees. The Group has over 74,400 employees. (http://www.tui-group.com/en/company/profile, http://de.statista.com/statistik/ daten/studie/30079/umfrage/umsatz-der-tui-ag/).

TUI has its own code of ethics, published by the headquarters in Hannover (http://www. tui-group.com/uuid/5a4a969abef14cdoa9oc04724dfob3e8).

The aspects of business are defined by the standards of the company's brand and segmentation of available jobs. TUI's standards are strictly defined by the contracts with which all branches, franchises and intermediaries must comply. There is a book of rules which starts from the point of how branch-offices should look like and, also, the book of rules on basic values of the company (ethical codex).

For obtaining a franchise, the bank guarantee is needed. TUI's partners do not create travels independently, but they act only as intermediaries. They are allowed to receive certain commision for a made trade and they are given the possibility to develop professionally with a small participation, or for free.

Each representative on his/her market has the right to the distribution of the TUI services to other legal entities, or agencies. The contract is concluded with these agencies, in other words, the contract on subagentura. Considering the fact that there are many countries in which TUI runs a business and that there is a difference in TUI's business activities, conditioned by the laws and customs of the country in which the business takes place, Serbia is taken as a case study in this research paper (www.tui-reisecenter.rs) and the relationship of TUI towards its tourists.

In order to avoid the same and other scandals, according to the subagent contract, the following applies:

- Impossibility of changing the price in relation to the ones published on the websites and in the reservation systems;

- Obligatory possession of a shop-window and premises on the street or in the shopping centre;

- The protection of TUI's brand;

- The prohibiton of the sale of TUI's products to other travel agencies arbitrarily;

- Delivery of a blank bill of exchange and a letter of authorization.

If the clients of subagents are not satisfied with the received service, all remarks and complaints must go to the agency where the service was bought. If an end-user decides to file a complaint directly to TUI, employees are obliged to direct him/her discreetly to the agent who had made the reservation.

The cooperation with the service providers is mostly defined in contracts signed by TUI Germany.

With the conclusion of the contract on the cooperation with hotels, the number and the type of the rooms being taken in lease are precisely defined and, also, the way of the capacity lease.

If the allotment contract without the guarantee of filling is concluded, a tour operator is obliged to notify the hotel about the number of sold accommodation entities and to return 
unsold rooms to the hotel so that it could offer them to others. The cooperation contract precisely defines the deadline during which a tour operator is obliged to return the unsold capacity. The contracts on fixed lease are concluded before the beginning of the season and the tour operator insists most often on the contingents with the best rooms for the reason that all rooms be in the same part of the hotel. TUI, while concluding a contract, insists on the contingents with the best rooms for the reason that they occupy large capacities. With the hotels of higher categories, the clauses of exclusivity are frequently introduced according to which guests are received with welcome at the reception desk or they are provided with additional services to which the guests who have arrived via other tour operators do not have the right.

When the contracts on the cooperation with airline companies are reached, the charter flights and classes on scheduled flights are concluded. If charters are concluded, the deadline for payment, travel conditions and price is precisely defined. The attention is paid even to the flight schedule in order to avoid the situations in which passengers lose one day in departure or in return, thus leaving room forcomlaints. In some cases, the contract with charters is made even with other tour operators, especially in the conditions when there is not a high season so that TUI takes on lease a certain percentage of seats while leaving one part to other tour operators. By the contract, the situation is often predicted that, in case that one of the lease-holders sells leased seats, he/she can take over as many seats from other lease-holders as they are ready to yield them up to him/her.

With respect to the tourist contracts, there is a practice with the agencies in Serbia of signing mainly standard contracts in the group arrangement in which a tourist cannot introduce special demands or change the provisions although it is advised in the tourism inspection. In $\mathrm{Eu}$, the providers of tourist services have begun to conclude precise contracts so as to protect themselves from the lawsuits for compensation, which has contributed to the improvement of quality of tourist services as a whole (http://potrosac.info/novosti/kako-se-stite-turisti-u-eusta-je-frankfurtska-lista).

\section{Ethical codex}

TUI has had its own ethical codex officialy since 2009, which was published by the headquarters in Hannover (http://www.tui-group.com/uuid/5a4a969abef14cdoa9oco4724dfob3e8). The TUI company commits itself by the codex to run a business according to the principles of business ethics and sustainable development, or according to the applicable laws, conventions and regulations. The respect of integrity of employees, business partners, shareholders and the media is an integral part of TUI's culture. The employees in the company are obliged to abide by the Codex, making effort in supporting human rights and developing an essential, ecological and socially balanced mechanism. The employees are obliged to abide by it in their sphere of influence. Each agency doing business outside Germany and Austria has the possibility of adapting its ethical codex to the laws and traditions of business operations of the country in which it runs a business (TUI documentation, 2010).

End-users are the most important for a successful business of each tour operator, because they themselves bring earnings to the company. Therefore, one must strictly take care of the way of treating them. The employees are obliged to listen to their clients carefully, treat them with respect. Formal communication is obligatory regardless of the age of a client. The sales agents most often communicate with their clients and they are obliged to inform them about all details associated with the travel. Moreover, the duty of the sales agents is to inform the clients about the visa requirements of the country to which they travel, general conditions of travel, way of 
payment, health insurance, insurance in the case of the travel cancellation and about the customs of the country to which they travel. An employee before a client represents the whole agency. Therefore, his/her bearing is very important. Considering the fact that the job of a sales agent is specific for the reasons that they only sell a story, the workers need to be well trained. The job of a sales agent is considered one of the most difficult jobs in tourism and the success of the salesperson depends on it how much he/she is communicative, helpful, resourceful, patient, eloquent and acquainted with the product being sold. Bearing in mind that TUI has over 10,0oo hotels in its offer, one can conclude that this job is extremely difficult and demanding because the subject matter is about the service with the aim to fascilitate for tourists the understanding of a destination in which they are going to stay. The sales agents provide the clients first with the information about the destination and particular attractiveness which the destination has, both in written form and immediate communication. The agents are expected to know the destination well because it is necessary to inform a potential passenger not only about the offer of the hotel, but, also, about the contents of the destination, culture, events, customs and about all other things in which the users of the service are interested. The managers and personnel, engaged in the creation of a package arrangement, must have broader knowledge of the destination. They are obliged to know about numerous details of the destinations belonging to their sector.

Considering the fact that they are in an everyday contact with many people of different characters, there is a chance that the problem in the communication between employees and clients arises. If he/she is not able to solve the problem with a client, the employee is required to consult with his/her superior who is obliged to solve all the remarks and complaints. Any higher tone of voice or entering a dispute with the client is sanctioned. If he/she estimates that the situation cannot be solved because the client is too much nervous, the employee is obliged to direct him at filing the written complaint in order to save time and ease the current situation. In order to reduce dissatisfaction, the employee is obliged to give the General Conditions of Travel to a passenger at each reservation.

All employees are obliged to protect the interests of passengers and to justify the confidence given to them. TUI, both in Germany and other countries of Europe where it operates and in Serbia, has a large number of regular clients. One needs to insist on creating the feeling of affiliation in a passenger, or the loyalty in a passenger. Passengers are different so that, therefore, their demands are sometimes unreal. The patience of agents is important due to this reason in order to discreetly direct the client at something which is real and not to fail to meet their expectations.

Clients meet the agency before the travel, during the travel, and one tends to make contact even after the travel has ended in order to come to know about the impressions of the passengers and to create their loyalty.

Tourist guides and TUI's representatives must also adopt certain codes of conduct and respect moral norms. They, as the representatives of a tour operator, are obliged to:

- Directly cooperate with persons who entrusted the job to them, considering the fact that local residents of the destination are often employed as representatives and guides;

- Have the licence of a tourist guide, according to the laws of the country in which they work and the badge of the agency which has hired them;

- Provide exact information;

- Be in accordance with ethical norms by their appearance and conduct;

- Be responsible in work and do work conscientiously;

- Bear in mind that they are in the workplace, regardless of the fact that all others are there on holiday; 
- Make most out of each programme by his/her performace. He/she must not allow that the quality of the programme reduces because of his/her mistake.

In order to feel safe in each destination, TUI has its representatives speaking German and one other world language at least. If any problem arises, the representatives in the destination are obliged to solve it as soon as possible. The representatives are obliged to stay at least for 45 minutes three times a week in each hotel which is in offer so as to be available for guests and to respect the time of visiting each hotel as well. The exact time when the representatives are in the hotel must be highlighted in the book on excursions organized by TUI and must be highlighted in the hall of the hotel. Each voucher contains the telephone numbers and e-mail addresses of the agents who are available for passengers 24 hours a day. In case that some of the passengers calls the representative out of the time when he/she is in the hotel, the representative is obliged to visit the passenger within the end the day at the latest (in the cases when nothing is urgent). In the cases when something is really urgent, he/she is obliged to appear as soon as possible.

The representative is obliged to organize the transport so that no one of the passengershas to wait for more than 45 minutes at the airport on the arrival in the destination. If he/she decides on the transport by bus, they must not have more than five hotels in their ride.The length of the ride is 30 minutes maximum between the first and the last stop between the hotels.

The very important feeling provided to tourists by TUI is the feeling of safety. So, in case that the civil war, bad weather conditions such as tsunami, hurricanes, volcanic eruptions or earthquakes happen in the destination, TUI sends airplanes within 24 hours in order to evacuate its passengers.When a large earthquake hit the Canary Islands in 2011, TUI was the first to send charter flights by which all passengers were safely evacuated in less than 24 hours. The operation of evacuation lasted several hours. The problem was the landing of airplanes because the volcano, which had erupted, emitted a huge amount of smoke. Two years ago, in 2012, when a German tour operator declared bankruptcy and left its passengers in Egypt, TUI took over all passengers, who were in hundreds, as its guests and, without charging them, made it feasible for them to continue their holiday after which, together with its toursist, TUI provided them with the return to their permanent residence.

That the profit is not in the first place is evidenced even by the information that the arrangement sale for Egypt was interrupted several times in 2013, because the German ministry of foreign affaires had estimated that Egypt was not a safe territory. It was pointed out to the clients on concluding the contract, when Egypt as a tourist destination was released, that there was a chance of not travelling if the situation became worse. All money was returned or re-booked for some other travel.

TUI, at every moment, guaranteesthe confidentiality of the dataof the people to which it has the access and all the facts given to TUI for insight whether they were the data of passengers or the private data of employees. Namely, the company guarantees its clients that all their data will be protected.

Employees are not allowed to give information about who and with whom someone travels, nor the information about how much some service has cost. The information about employees is held in safes by the company and it is not allowed to give personal data of employees unless it is necessary for business. Each abuse for personal use is considered to be the violation of official duty (TUI documentation, 2013).

As one of dilemmas of business ethics, the problem of a so-called reservation fee appears. Namely, by contracts, any change in the price with regard to the ones published on the web- 
sites and in the reservation systems is strongly prohibited. Tour operators and travel agencies introduce the reservation fees aiming at additional earnings. There is no breach of the contract in this way, but the question of business ethics arises. Should clients be charged for the interview with sales agents? Should clients pay for compensation because they use the services provided by a tour operator? This practice is applied even by some foreign tour operators doing business in Serbia. The research conducted by TUI in Serbia indicates that this causes great dissatisfaction in clients so that they are ready to pay for the same services via another agency (TUI documentation, 2011). This research made TUI change its decision about charging for the reservation fee, which, according to TUI's statistics, made even 400 passengers organize their travel during one year via TUI.

In order to prevent some of the stated complaints of tourists to the Ministry (www.blic.rs/ Vesti/Tema-Dana/198198/Deset-najcescih-prevara-turistickih-agencija, taken from the tourist inspection of the Ministry of Economy and Regional Development of the Republic of Serbia) (Simat, Dragin, Dragićević, 2012), TUI puts the number of overnights in its programme and not the number of days. What is characteristic for almost all German tour operators and, also, for TUI is their own categorization of hotels and apartments. State authorities (those which introduce the laws on the categorization of facilities) are often ununiformed or yielding to some facilities so that a given category is not objective. This example is repeatedly found in Greece where hotels have more stars than they deserve while there are the opposite examples in Spain - hoteliers seldom decide to accept worse categorization in order to avoid high taxes. Thus, TUI has its own categorization, which further causes a small number of complaints, because the clients bear in mind a real, and according to the same criteria, categorization of the facility in which they stay.

\section{The insurance}

TUI is insured with the policy of 100,000,000 euros in case of insolvence and of responsibility. TUI signs the contract with an insurance company by which TUI offers the health insurance services and the insurance in case of the cancellation. TUI cooperates with DDOR in Serbia. The insurance policy from responsibility is made on 100,00o euros while the insolvence policy is made on 15,000 euros. The policy in Serbia is signed only for lawful reasons, but the policy on 100,000,00o euros actually covers all risks of TUI as well, in Serbia. A tour operator has the right to sell the insurance from more insurance companies, but for the reasons of business, relationships, it decides upon one. Insurance companies pay premiums to travel agencies for sold policies.

Considering the fact that, in Serbia, the health insurance and the insurance of the arrangement cancellation are not obligatory by law, a problem arises in the situations when there are physical injuries, or the cancellation of the arrangement by a passenger. According to the standards in Germany, a client has the right to compensation not only if he/she becomes injured during the travel, but also if the arrangement is cancelled due to his/her disease, death of a family member or dismissal. A problem arises in Serbia when a client of an agency cannot travel without taking the insurance in case of cancellation. The characteristic of all German tour operators is that, in case of the travel cancellation at the moment when there are more than 30 days till the departure, a tour operator retains $25 \%$ of the total arrangement price. In the cases when a passenger has the insurance of cancellation, the insurance company is obliged to refund the lost money to the passenger, between $70 \%$ and $90 \%$ depending on the concluded policy, i.e. the participation. In case that the passenger does not have the policy 
on the cancellation insurance, the costs of the cancellation are at his/her expense. This problem causes dissatisfaction in passengers. On the basis of the submitted documentation in Germany, the insurance company suffers the difference in price, i.e. it covers the costs of a passenger. Taking into account the fact that the cancellation insurance is rarely taken in Serbia and that seven out of a thousand passengers take the cancellation insurance (TUI documentation, 2013), this field remains uncovered.

\section{The guarantee of confidentiality}

For a better service, TUI has introduced the snow guarantee which regulates that if there is not enough snow on ski slopes in the period when a passenger paid his/her travel, he/she can change the hotel free of charge or make a reservation for some other travel. The problem is solved in this way so that tourists do not return dissatisfied with the received service.

With the compensation for failure to fulfill travel contracts, TUI sticks to the rules prescribed by the Frankfurt list published for the first time in Neue Juristische Wochenschrift magazine. The same standards are applied even in Serbia for the passengers travelling via TUI. Foreign tour operators solve all complaints via the key which isalso often referred to by the state court in Germany although the Frankfurt list is not an official document or law.

\section{The Frankfurt list and the analysis of complaints with TUI}

The Frankfurt list includes the following categories: accommodation, food, transport and other (http://reisemangel.de/mediapool/74/745854/data/www_1_.reisemangel.de_Frankfurter_Tabelle_zur_Reisepreisminderung.pdf). Each of the category specifies a possible percentage-based right to the refund of the paid money depending on the degree of defectiveness of the travel arrangement. The right to compensation is very precisely defined with the aim to protect both passengers and tour operators. The categories by which the Frankfurt list is divided are accommodation (a possible percentage of the refund is between $5 \%$ and $25 \%$ ), food (the percentage of the refund is between $5 \%$ and $30 \%$ ), transport (5\%-10\%), other (between $5 \%$ and $20 \%)$.

According to the statistics of the whole company, the complaints filed with TUI are made by only $0.1 \%$ of passengers. From that percentage, $30 \%$ is considered unfounded. With the complaints which are unfounded, employees are obliged to attempt to keep the clients and to discreetly tell them that their complaints are not founded. The rest of the passengers who have grounds for the complaint are given the compensation in the form of a partial refund, gift voucher for the next travel, etc. Mistakes are possible everywhere and it is very important to correct them in order to keep the client.

A more detailed analysis has been made on the basis of the insight into two-year business operations of TUI in Serbia. From the total number of the arrangements in the period from July 2012 to July 2014, the percentage-based presence of complaints is $0.01 \%$, which is considered an uncommonlysmall percentage.

From all lodged complaints, $40 \%$ were considered unfounded whereas $60 \%$ had foundation and the clients had the right to compensation, i.e. to a partial refund.

The largest number of complaints, even $70 \%$, pertains to the degree of comfort (in rooms, there are not any safe, minibar, air-conditioner, TV, extra bed instead of a standard size bed). In this case, according to the Frankfurt list, a passenger has the right to compensation between $5 \%$ and $25 \%$. From the stated complaints, even $50 \%$ refers to the surface of the room. Consider- 
ing the fact that the surface of certain type of a room is clearly stated in the hotel description, a tour operator is obliged to provide the same type of the room for which a passenger has paid. Around $10 \%$ of complaints pertains to the lack of a balcony or terrace, $20 \%$ refers to the bad quality of an extra bed. Then, $5 \%$ of the passengers had a remark on extra payment for the use of a safe, minibar, air-conditioner or baby crib and $15 \%$ on insufficiently clean rooms. As one of the reasons for the complaint, relating to uncleanliness, the passengersstate old furniture in $5 \%$ of cases, which cannot be assigned at all to the same category.

Around $10 \%$ of complaints pertains to the remarks on the accommodation in the economy rooms, or in the rooms which are cheaper for the reason of their worse position (not far away from the lift, kitchen, with the view on the wall, of smaller surface, or they are in an unrestored part of the hotel which is sometimes even worse categorized). These complaints are considered unfounded because it has been stated both in the travel contract and hotel description what deficiency in the rooms exists. In case that it has not been stated in the travel contract that there is the economy room, the passenger has the right to refund.

Around $12 \%$ of the complaints pertains to the food service. This problem is difficult to be solved because the remarks on food are often subjective. If the given food service does not match the categorization of the hotel, a passenger has the right to a refund between $5 \%$ and $30 \%$. These complaints are most often unfounded in practice because it is not specified anywhere in catalogues or on the websites of agencies what the food service concretely includes. There is not a rule that a hotelier must serve a certain number of dishes, how much the portion of vegetarian dishes, meat dishes and the like is. The only difference found in the hotel desriptions is whether there is a self-service (buffet) or menu. If the hotelier breaks this rule, it is easily proved and there is not a problem of receiving the complaint (TUI documentation, 2014).

The rest of the complaints pertains to the insufficiently arranged beach, the distance of the parking area from the hotel, closed parts of the hotel (swimming pools, the spa and wellness premises). According to these criteria, passengers have the right to compensation of $5 \%$ to $20 \%$.

\section{The example of the unfounded complaint}

Dear Sir or Madam,

We wish to file the complaint the accommodation in the hotel on Rhodes. As it is stated on the receipt which we were given to in your agency, the hotel has 4 stars, which you have also stated according to your categorization. Our impression is that the hotel does not have 4 stars and our remarks refer to the bad appearance of the corridor leading to our room. The bed was a bit uncomfortable and the bathroom was small. Our suggestion is that $50 \%$ of paid money be returned to us.

There is no right to compensation, because the passenger did not consult the representative in the destination in order to be moved to another room. In case that the problem cannot be solved, they make a record in which they state the problem and the client files the complaint together with the record on return. The right to compensation is gained in this way.

\section{The example of a grouded complaint}

Dear Sir or Madam,

On this occasion, I am filing the complaint about the received accommodation in Corfu. As you can see from the correspondence, I had kindly asked for the reservation of a room with a double bed and with direct sea view (extra payment made). I was given a double room with side sea view (the photo is in the attachement). 


\section{Conclusion}

This research paper considers the mechanisms which TUI in Serbia uses in order to develop responsible business, in the first place towards the end-users of its services - tourists. It implicits various contracts which TUI signs with its partners, numerous service providers (e.g. hotels, airline companies, insurance companies) and, finally, with its tourists. Besides this, the mechanisms are even ethical codex, insurance policy, guarantee of confidentiality and the Frankfurt list. Finally, the subject of this research was also the complaints or the approach of solving possible complaints of the end-users of TUI's services. For theses reasons, all arrangements, sold and realized in the period from July 2012 to July 2014 in TUI in Serbia, are included for the needs of this research paper.

From the previously stated, one can see that a very small number of complaints has been filed in relation to the total number of travels realized during one financial year in TUI(Serbia) - $0.01 \%$. The information that $40 \%$ of complaints is unfounded refers to the fact that passengers are not acquainted with their rights and obligations. Moreover, there is a possibility that passengers do not believe in the legal system in Serbia and that this is one of the reasons for which they do not file complaints.

When the reasons for complaints, published by the Ministry of Economy and Regional Development, are compared with the complaints filed by TUI's passengers, one comes to the conclusion that the reasons are mainly the same although some complaints do not appear, e.g. the cancellation of an arrangement as a consequence of the insufficient number of registered passengers.

The next conclusion pertains to the complaints associated with the abridgement of stay, i.e. to the unused first and last day. According to the conducted research, these complaints have not happened yet, which can be linked to a better defined duration of the travel arrangement with TUI.

However, TUI in Serbia is not able to fully implement the Frankfurt list, because the legal obligations of tourists in Serbia are not the same as those in Germany.

The health insurance and the arrangement cancellation insurance arenot mandatory by law in Serbia so that a problem arises in the situations when physical injuries or the cancellation of the arrangement by a passenger happen. The acceptance of the Frankfurt list key in Serbia would enable the increase in the quality of providing services, because a stricter book of rules and stricter punishment measures would force tour operators and travel agencies to conclude the contracts on travel more precisely. Even so many scandals would be avoided in this way, caused by national travel agencies in previous years in the summer season that e.g. tourists were deprived of the paid arrangements in some foreign destinations, which is an indicator of insufficient consciousness of the main actors in the tourism industry of the importance of business ethics and socially responsible business.

\section{Acknowledgement}

We wish to express our gratitude to the TUI Company for providing us with the insight into its documentation and for contributing to the writing of this research paper. 


\section{References}

Čavlek, N. 1998. Touroperators and global tourism, Zagreb, Golden marketing.

Dragin, A. 2011. Tourism and business ethics. University of Novi Sad Faculty of Sciences, Department of geography, tourism and hotel management, Novi Sad.

Simat, K., Dragin, A., Dragićević, V. 2012. The Institutionalization of Business Ethics of Travel Agencies in Serbia. Turizam, 16 (3), 113-123.

Simat, K., Dragin, A. 2012. Business Ethics - an Element of Successful Business of Travel Agencies. Researches Review of the Department of Geography, Tourism and Hotel Management, 41, 297-309.

TUI dokumentation, 2009- 2014 .

\section{|| || | ||}

www.antas.rs/ClanicePretraga.aspx

www.blic.rs/Vesti/Tema-Dana/198198/Deset-najcescih-prevara-turistickih-agencija www.dgt.pmf.uns.ac.rs/download/etikamanipulacija.pdf http://www.finanztip.de/recht/reiserecht/frankfurter-tabelle.htm http://www.palgo.org/files/Agenda2_net.pdf potrosac.info/novosti/kako-se-stite-turisti-u-eu-sta-je-frankfurtska-lista http://reisemangel.de/mediapool/74/745854/data/www_1_.reisemangel.de_Frankfurter_

Tabelle_zur_Reisepreisminderung.pdf http://www.turistplus.hr/upload/content/frankfurtske_tablice.pdf www.yuta.rs http://www.yuta.rs/sr/yuta/arbitraza.asp www.kg-cci.co.rs/pdf/zakoni/ kodeks_poslovne_etike http://archiv.jura.uni-saarland.de/projekte/Bibliothek/text.php?id=349 http://www.turizam.merr.gov.rs/images/stories/turisticka\%2oinspekcija/izvestaji/Izvestaj\%2o o\%2oradu\%2oSektora\%2oturisticke\%2oinspekcije\%2ou\%202010.\%2ogodini.pdf http://www.turizam.merr.gov.rs/images/stories/materijal/Oduzete\%2olicence\%2oturistickim\%2oagencijama.pdf http://www.tui-group.com/en/company/profile http://de.statista.com/statistik/daten/studie/30079/umfrage/umsatz-der-tui-ag/ http://www.tui-group.com/uuid/5a4a969abef14cdoa9oco4724dfob3e8 